\title{
Lingual-facial Trunk Arising from the External Carotid Artery: A Case Report
}

\author{
Tronco Linguo-Facial como Rama de la Arteria Carótida Externa: Reporte de un Caso
}

Constanza Pantoja Gonzalez*; César Coronado Gallardo ${ }^{* * *}$; Pedro Aravena Torres ${ }^{* * * *}$ \& Iván Suazo Galdames ${ }^{* * * * *}$

PANTOJA, G. C.; CORONADO, G. C.; ARAVENA, T. P. \& SUAZO. G. I. Lingual-facial trunk arising from the external carotid artery: A case report. Int. J. Morphol., 32(3):1108-1110, 2014.

SUMMARY: The variations in the origin of the facial and lingual arteries are very important in maxillofacial, head and neck surgery procedures. This study is a case report in which the common origin is described in the facial and lingual artery in a lingual-facial trunk (LFT) on the left side of a female corpse from Spain. In the examination, a diameter of $2.17 \mathrm{~mm}$ and a length of $8.84 \mathrm{~mm}$ are shown. It was located $12.04 \mathrm{~mm}$ from the carotid bifurcation and $9.31 \mathrm{~mm}$ from the origin of the superior thyroid artery. The variation in biometric values shown, are anatomical findings in the neck dissection of a corpse. Moreover, taking into account the surgical procedures, which involve the origin of facial and lingual artery, because it is the most common variation and could cause complications.

KEY WORDS: Lingual-facial trunk; External carotid artery; Artery bifurcation.

\section{INTRODUCTION}

The external carotid artery (ECA) irrigates large areas of the head and the neck, being a vascular element of a great importance in surgical and radiological procedures (Fasan et al., 2009; Hayashi et al., 2005). At the height of the intervertebral disc, at the upper edge of the thyroid cartilage, between the third and fourth vertebra (Anu et al., 2007). From there, its cervical branches begin in ascending order: The upper thyroid artery (UTA), lingual artery (LA) and facial artery (FA).

It is known that ECA presents variations in the distribution in its anterior branches (Iwai et al., 2012; Nirmaladevi \& Sruthi, 2010), finding common origins in forming trunks, which can be found as: tyro-linguo-facial truncus, tyro-lingual truncus and linguo-facial truncus (Lucev et al., 2005). The lingual-facial trunk (LFT) is an arteriosus truncus, where lingual and facial artery begins. It is located over the superior thyroid artery, it has shown in percentage between $6 \%$ to $20 \%$, in analyzed cases and generally, it is the most common of variations (Troupis et al., 2011; Jadhav et al., 2011) not showing preference for one side or the other (Fasan et al.).
These anatomical variations remain unnoticed, during the life of an individual, but they become more important when there are changes associated with aging, such as loss of elasticity of the trunk or aneurysms development of the trunk, which are pathologic (Zümre et al., 2005).

\section{CASE REPORT}

A 103-year-old human spanish female corpse from the Laboratory of Morphofunction, Department of Anatomy, Universidad Diego Portales, Chile, was dissected. This corpse was submitted to embalming process through the carotids, injecting a mixture of formaldehyde, alcohol, distilled water, and urotropine, with death date average of two days. In addition, to observing in detail, the path of the arterial system was injected with a solution of latex mark, Laitex MX-10, mixed with a red vermillion dye universal mark (Alp Paintings) by the same way. The dissection of left side in the neck was performed according to the conventional technique, carefully pulling the skin, the deep

\footnotetext{
* Escuela de Odontología, Facultad de Salud y Odontología, Universidad Diego Portales, Santiago. Chile.

** Departamento de Morfofunción, Facultad de Medicina, Universidad Diego Portales, Santiago. Chile.

*** Instituto de Anatomía, Histología y Patología. Facultad de Medicina, Universidad Austral de Chile, Valdivia, Chile.

***** Dirección de Postgrado e Investigación. Universidad Autónoma de Chile, Santiago, Chile.
} 
cervical fascia, sternocleidmastoid muscle and separating the internal jugular vein and vagus nerve on the left side of the body, The LFT was observed over the beginning of the superior thyrod artery (Fig. 1).

During the complete neck dissection, the same anatomical variation was not found on the right side. The measurements were made with a digital caliper Mitutoyo ${ }^{\circledR}$ branded, using two decimals to measure lengths and diameters. A photographic register was made, using a Fujifilm® camera FINEPIX S 2500 HD.

The LFT measured $8.84 \mathrm{~mm}$ of length, from its beginning in the ECA, until its bifurcation in FA and LA. It had a diameter larger than $2.17 \mathrm{~mm}$, which was comparatively continuous in all its extension. The LFT was located $12.04 \mathrm{~mm}$ of the carotid bifurcation and $9.31 \mathrm{~mm}$ from the beginning of superior thyroid artery.

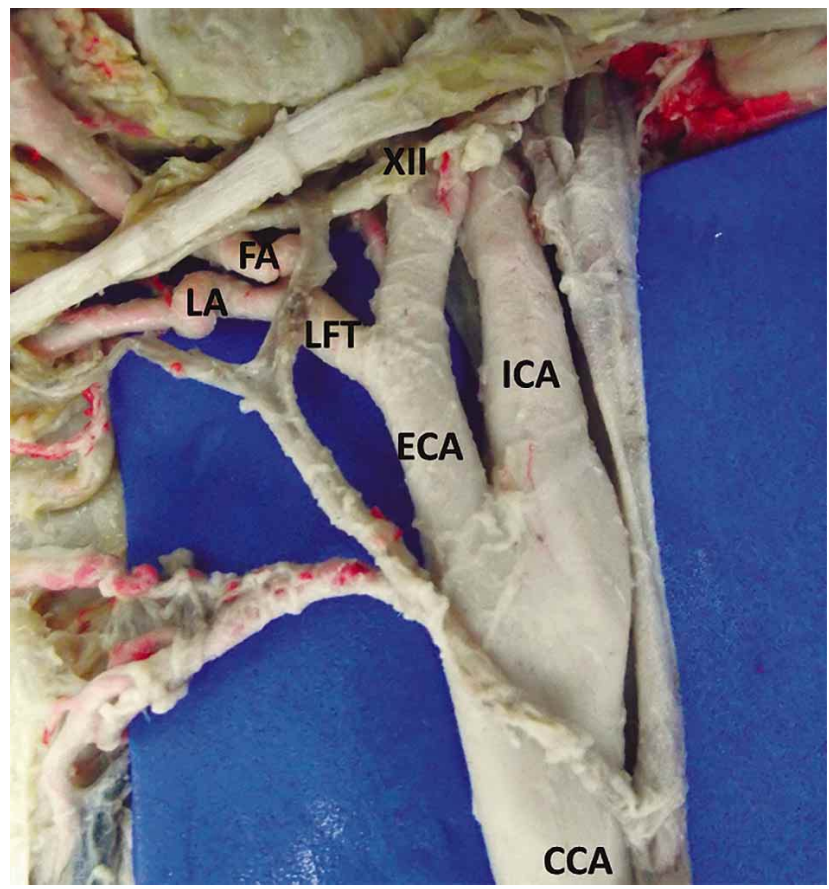

Fig. 1. The image shows the bifurcation of the common carotid artery (CCA) in the external carotid artery (ECA) and the internal carotid artery (ICA) and the relationship with the venous structures, and the hypoglossal nerve (XII), the lingual-facial trunk (LFT), the facial artery (FA) and the lingual artery (LA).

\section{DISCUSSION}

The case report is presented of a common trunk of FA and LA from the ECA. The classic anatomical literature (e.g., see Human Descriptive Anatomy, Testut or Human Anatomy, Rouviere) and recent reports (Fazan et al.; Mata et al., 2012) describe with more frequency cases of origin of the LA and FA directly from the ECA. However the LFT is presented as the most common origin from FA and LA.

Mata et al. (2012) report a LFT frequency in $19.9 \%$ of dissections and at the same time, Troupis et al. only two cases (6\%). Fazan et al. present it most frequently, $20 \%$ in the right side $(\mathrm{n}=8)$ and $24 \%$ in the left side $(\mathrm{n}=10)$, only two corpses $(4.9 \%)$ show a bilateral lingual-facial trunk information that represents low level of LFT in both sides of the neck, as our reports shows.

Due to LFT length and diameter reported, matched with the literature: length between $7.3 \mathrm{~mm}$ and $9.4 \mathrm{~mm}$ in its origin and artery bifurcation (Fazan et al.; Troupis et al.) and length of $7.9 \mathrm{~mm}$ to $11.6 \mathrm{~mm}$ in its origin and the bifurcation of the common carotid artery (Fazan et al.; Troupis et al.). This micrometric information of the vessels is mainly important in the planning of performed procedures in the neck area, which involves many fields, such as general surgery and maxillofacial surgery (Troupis et al.). The knowledge of the variations in the ECA branches is very important for surgical, radiologic and diagnostic procedures and interventions in the head and neck (Iwai et al., 2013). Its presence justifies the ligation of ECA and its branches in surgeries that cover upper areas in the insertion of digastric muscle and halibut nerve (Bouloux \& Perciaccante, 2009).

Ahmed et al. (2012) described that lingual and facial arteries originating from an LFT had thicker in its wall and higher density of elastic fibers, which is associated according to Li et al. (2007) to present chances developing pseudoaneurysms in the ECA after catheterization procedures.

In conclusion, a LFT report is presented and its biometrical values as anatomical findings in the neck dissection of a corpse. Since these variations are asymptomatic, the detection will depend on imaging tests (Troupis et al.) for characterize the vascular anatomy and reduce the chances of collateral injures.

PANTOJa, G. C.; CORONADO, G. C.; ARAVENA, T. P. \& SUAZO. G. I. Tronco arterial linguo-facial como rama de la arteria carótida externa: Reporte de un caso. Int. J. Morphol., 32(3):1108-1110, 2014.

RESUMEN: Las variaciones del origen de la arteria facial y lingual son importantes en los procedimientos de cirugía maxilofacial y de cabeza y cuello. Reportamos un caso en el que se describe el origen común de las arterias facial y lingual en un tronco linguofacial en el lado izquierdo en el cadáver de una mujer de origen español. En la examinación, el tronco presentó un diá- 
metro de 2,17 $\mathrm{mm}$ y una longitud de $8,84 \mathrm{~mm}$. Se ubicó a 12,04 mm de la bifurcación carotidea y a $9,31 \mathrm{~mm}$ del origen de la arteria tiroidea superior. La variación en los valores biométricos presentados constituyen un hallazgo anatómico en una disección de cuello de un cadáver, además ser tomada en cuenta en los procedimientos quirúrgicos que involucren el origen de la arteria facial y lingual, pues al ser la variación más común podría generar complicaciones.

PALABRAS CLAVE: Tronco linguo-facial; Arteria carótida externa; Bifurcación arterial.

\section{REFERENCES}

Ahmed R.; Al-Shaarawy, S.; Atteya, M.; Al-Fayez, M.; Aldahmash, A.; Mohal S. \& Aziz, R. Anatomical variations of lingual and facial arteries in male cadavers and histological study of their structure. Int. J. Integr. Biol,, 13(1):36-39, 2012.

Anu, V. R.; Pai, M. M.; Rajalakshmi, R.; Latha, V. P.; Rajanigandha, V. \& D'Costa, S. Clinically-relevant variations of the carotid arterial system. Singapore Med. J., 48(6):566-9, 2007.

Bouloux, G. F. \& Perciaccante, V. J. Massive hemorrhage during oral and maxillofacial surgery: ligation of the external carotid artery or embolization? J. Oral Maxillofac. Surg., 67(7):1547$51,2009$.

Fazan, V. P.; da Silva, J. H.; Borges, C. T.; Ribeiro, R. A.; Caetano, A. G. \& Filho, O. A. An anatomical study on the lingual-facial trunk. Surg. Radiol. Anat., 31(4):267-70, 2009.

Hayashi, N.; Hori, E.; Ohtani, Y.; Ohtani, O.; Kuwayama, N. \& Endo, S. Surgical anatomy of the cervical carotid artery for carotid endarterectomy. Neurol. Med. Chir. (Tokyo), 45(1):259, 2005.

Iwai, T.; Izumi, T.; Inoue, T.; Maegawa, J.; Fuwa, N. \& Mitsudo, K. Tohnai, I. Thyrolingual trunk arising from the common carotid artery identified by three-dimensional computed tomography angiography. Surg. Radiol. Anat., 34(1):85-8, 2012.

Iwai, T.; Izumi, T.; Inoue, T.; Fuwa, N.; Shibasaki, M.; Oguri, S.; Mitsudo, K. \& Tohnai, I. Thyrolinguofacial trunk arising from the carotid bifurcation determined by three-dimensional computed tomography angiography. Surg. Radiol. Anat., 35(1):75-8, 2013.

Jadhav, S. D.; Ambali, M. P. \& Patil, R. J. Anatomical variation of the origin of the right lingual artery. Int. J. Anat. Var., 4:75-6, 2011.

Li, S. H.; Hsu, S. W.; Wang, S. L.; Chen, H. C. \& Huang, C. H. Pseudoaneurysm of the external carotid artery branch following radiotherapy for nasopharyngeal carcinoma. Jpn. J. Clin. Oncol., 37(4):310-3, 2007.
Lucev, N.; Bobinac, D.; Maric, I. \& Drescik, I. Variations of the great arteries in the carotid triangle. Otolaryngol. Head Neck Surg., 122(4):590-1, 2000.

Mata, J. R.; Mata, F. R.; Souza, M. C.; Nishijo, H. \& Ferreira, T. A. Arrangement and prevalence of branches in the external carotid artery in humans. Ital. J. Anat. Embryol., 117(2):65-74, 2012.

Nirmaladevi, M. \& Sruthi, G. Linguo-Facial Trunk - a case report. Anat. Karnataka, 4(2):54-6, 2010.

Troupis, T. G.; Dimitroulis, D.; Paraschos, A.; Michalinos, A.; Protogerou, V.; Vlasis, K.; Troupis, G. \& Skandalakis, P. Lingual and facial arteries arising from the external carotid artery in a common trunk. Am. Surg., 77(2):151-4, 2011.

Zümre, O.; Salbacak, A.; Cicekcibasi, A. E.; Tuncer, I. \& Seker, M. Investigation of the bifurcation level of the common carotid artery and variations of the branches of the external carotid artery in human fetuses. Ann. Anat., 187(4):361-9, 2005.

\section{Correspondence to:}

Prof. Dr. César Coronado G.

Departamento de Morfofunción

Facultad de Medicina

Universidad Diego Portales

Ejército 141

Santiago

CHILE

Email: cesar.coronado@udp.cl

Received: 12-06-2014

Accepted: $11-08-2014$ 